\title{
PENGARUH LITERASI KEUANGAN TERHADAP KINERJA KEUANGAN KOPERASI PEGA WAI NEGERI DI BANDAR LAMPUNG, PERILAKU PENGELOLAAN KEUANGAN PENGURUS KOPERASI SEBAGAI VARIABEL INTERVENING
}

\author{
Liya Ermawati, S.E.,M.S.Ak \\ Liyaermawati79@gmail.com \\ Ainul Fitri, S.E., M.Acc \\ Ainulpipit13@gmail.com \\ Muhammad Thoriq \\ Muhammadthoriq88@gmail.com \\ UIN Raden Intan Lampung
}

\begin{abstract}
Banyaknya koperasi yang tidak aktif dalam menjalankan unit koperasi karena diduga masih memiliki kendala pada masalah keuangan.Kebutuhan individu dan produk finansial yang semakin kompleks menuntut para pengurus koperasi untuk memiliki literasi keuangan yang memadai.Individu membutuhkan pengetahuan keuangan dasar serta kemampuan untuk mengelola sumber daya keuangan secara efektif demi kesejahteraan dan perkembangan koperasi yang lebih baik.

Kemampuan seseorang dalam menggunakan uang sangat bergantung pada pengetahuan yang dimiliki, semakin baik literasi keuangan yang dimiliki oleh seseorang maka menunjukkan semakin baik perilaku pengelolaan keuangan yang kemudian akan berdampak pada kinerja keuangannya. total keseluruhan sampel berjumlah 50, dengan metode analisis jalur, Analisis jalur digunakan untuk menganalisis pola hubungan antar variabel dengan tujuan untuk mengetahui pengaruh langsung maupun tidak langsung seperangkat variabel bebas terhadap variabel terikat

Berdasarkan hasil pengolahan data diatas dapat diketahui nilai pengaruh langsung antara variable perilaku pengelolaan keuangan terhadap kinerja keuangan adalah sebesar 0.681 sedangkan pengaruh tidak langsung antara variable $\mathrm{x} 1, \mathrm{x} 2$ dan $\mathrm{x} 3$ terhadap kinerja keuangan melalui perilaku pengelolaan keuangan sebesar $0.0051(0.367 \times 0.480 \mathrm{x}$ 0.029). dengan membandingkan kedua nilai tersebut dapatdibuktikan bahwa pengaruh variable pengetahuan $\mathrm{X} 1$, pemahaman $\mathrm{X} 2$, dan penerapan $\mathrm{X} 3$ terhadap kinerja keuangan secara langsung lebih kecil dari pada pengaruh variable pengetahuan $X 1$, pemahaman X2dan penerapan X3 terhadap kinerja keuangan $\mathrm{Z}$ melalui perilaku pengelolaan keuangan $\mathrm{Y}$, sehingga dapat disimpulkan bahwa perilaku pengelolaan keuangan merupakan intervening bagi literasi keuangan dengan kinerja keuangan seseorang memiliki literasi keuangan yang baik ditambah dengan perilaku dalam mengelola keuangan yang tepat maka orang tersebut dapat dikatakan sejahtera dalam hal keuangannya, Karena dengan seorang pengurus memiliki skill yang baik dalam mengelola keuangannya, pengurus koperasi tersebut akan terhindar dari masalah keuangan sehingga kinerja keuangan koperasi akan tercapai dengan maksimal.
\end{abstract}

Keyword : literasi keuangan, perilaku pengelolaan keuangan dan kinerja keuangan koperasi

\section{ABSTRACT}


The number of cooperatives is not active in running cooperative units because it is suspected that they still have problems with financial problems. The increasingly complex needs of individuals and financial products require cooperative managers to have adequate financial literacy. Individuals need basic financial knowledge and the ability to manage financial resources effective for better welfare and development of cooperatives.

The ability of a person to use money depends on the knowledge they have, the better the financial literacy that is owned by someone, the better the financial management behavior will then have an impact on their financial performance. the total sample totaled 50, with the path analysis method, path analysis was used to analyze the pattern of relationships between variables in order to determine the direct or indirect effects of a set of independent variables on the dependent variable

Based on the results of data processing above, it can be seen that the direct effect of variable financial management behavior on financial performance is 0.681 while the indirect effect between variables $\mathrm{x} 1, \mathrm{x} 2$ and $\mathrm{x} 3$ on financial performance through financial management behavior is $0.0051(0.367 \times 0.480 \times 0.029)$. by comparing the two values, it can be proved that the effect of knowledge variable X1, understanding $\mathrm{X} 2$, and the application of $\mathrm{X} 3$ on financial performance is directly smaller than the effect of knowledge variable $\mathrm{X} 1$, understanding $\mathrm{X} 2$ and the application of $\mathrm{X} 3$ on financial performance $\mathrm{Z}$ through $\mathrm{Y}$ financial management behavior, so it can be concluded that financial management behavior is intervening for financial literacy with financial performance

a person has good financial literacy coupled with proper financial management behavior, the person can be said to be prosperous in terms of finance, because with an administrator having good skills in managing his finances, the cooperative board will avoid financial problems so that cooperative financial performance will be achieved maximally.

Keywords: financial literacy, financial management behavior and cooperative financial performance

\section{Pendahuluan}

Didalam kehidupan ekonomi yang semakin pesat peran koperasi dianggap masih memiliki peranan yang sangat penting dalam membantu kehidupan ekonomi rakyat. Koperasi merupakan suatu wadah yang diadakan oleh lembaga pemerintah untuk membela kepentingan para anggotanya.Ini terlihat dari usaha pemerintah dalam memberikan bimbingan, kemudahan, dan perlindungan kepada koperasi.Semakin tahun perkembangan koperasi diindonesia semakin berkembang, hal ini ditunjukkan dengan data BPS dari tahun ke tahun mengalami kenaikan berikut data BPS.

\begin{tabular}{|c|c|c|c|c|c|}
\hline No. & Indikator & Satuan & 2013-2014 & 2014-2015 & 2015-2016 \\
\hline 1 & Jumlah Koperasi & Unit & 203701 & 209488 & 212135 \\
\hline 2 & Pertumbuhan Koperasi & Persen & 4,84 & 2,84 & 1,26 \\
\hline 3 & Jumlah Koperasi Aktif & Unit & 143007 & 147249 & 150223 \\
\hline 4 & Prosentase Koperasi Aktif dari Total Jumlah Koperasi & Persen & 70,20 & 70,29 & 70,81 \\
\hline 5 & Pertumbuhan Jumlah Koperasi Aktif & Persen & 2,65 & 2,97 & 2,02 \\
\hline 6 & Jumlah Anggota Koperasi Aktif & Orang & 35258176 & 36443953 & 37783160 \\
\hline
\end{tabular}


Namun dengan perkembangan yang begitu baik masihbanyak pelaku unit koperasi yang tidak terurus dan terancam dibubarkan oleh dinas Koperasi dan UMKM tahun 2018 ini, Sumber: Effran Kurniawan, Lampost.co 18 Feb 2018 “ BANDAR LAMPUNG (Lampost.co), Sebanyak 2.204 koperasi tidak aktif di Lampung terancam dibubarkan tahun 2018 ini. Pasalnya, Kementerian Koperasi dan Usaha Kecil dan Menengah (UMKM) segera memutuskan agar lembaga keuangan berasas kekeluargaan yang tidak rajin dalam kegiatan keuangan dihapuskan.Asisten I Pemerintah Provinsi Bidang Pemerintahan dan Kesejahteraan Rakyat, Heri Suliyanto menjelaskan hingga 31 Desember 2017 lalu tercatat terdapat 5.325 unit koperasi dengan 3.121 lembaga aktif dan 2.204 unit tidak aktif. Sementara pada UMKM terdapat 99.307 unit. "

Kebutuhan individu dan produk finansial yang semakin kompleks menuntut para pengurus koperasi untuk memiliki literasi keuangan yang memadai.Individu membutuhkan pengetahuan keuangan dasar serta kemampuan untuk mengelola sumber daya keuangan secara efektif demi kesejahteraan dan perkembangan koperasi yang lebih baik. Dengan pengelolaan keuangan yang baik dan tepat ditambah oleh literasi keuangan yang baik diharapkan bisa mendapatkan manfaat yang maksimal dari uang yang dimilikinya saat ini sehingga pada akhirnya dapat bermanfaat bagi peningkatan kinerja keuangannya.Berdasarkan latar belakang di atas, maka peneliti tertarik untuk mengambil judul "PENGARUH LITERASI KEUANGAN TERHADAP KINERJA KEUANGAN KOPERASI PEGAWAI NEGERI DI BANDAR LAMPUNG, PERILAKU PENGELOLAAN KEUANGAN PENGURUS KOPERASI SEBAGAI VARIABEL INTERVENING"

\section{Landasan Teori dan Metodologi}

\section{Landasan Teori}

Lusardi dan Mitchell (2013) mendefinisikan paham keuangan sebagai pengetahuan keuangan dan kemampuan untuk mengaplikasikannya (knowledge and ability) dimana mencakup pengetahuan dasar mengenai keuangan pribadi (basic personalfinance), pengetahuan mengenai manajemen uang (cash 
management),pengetahuan mengenai kredit dan utang, pengetahuan mengenai tabungan dan investasi serta pengetahuan mengenai risiko. Kemampuan seseorang dalam menggunakan uang sangat bergantung pada pengetahuan yang dimiliki, semakin baik literasi keuangan yang dimiliki oleh seseorang maka menunjukkan semakin baik perilaku pengelolaan keuangan yang kemudian akan berdampak pada kinerja keuangannya (Perry dan Morris, 2005).

literasi keuangan dan pengetahuan keuangan merupakan aset yang penting dalam sebuah perusahaan terutama usaha kecil. Literasi keuangan berarti seorang individu harus memiliki kepercayaan diri dalam menggunakan pengetahuan keuangannya untuk membuat sebuah keputusan keuangan. Literasi keuangan tidak hanya diukur dari bagaimana seseorang memiliki informasi tentang keuangan namun bagaimana ia bisa menerapkannya dengan tepat.

Menurut Huston (2010), literasi keuangan didefinisikan sebagai pengetahuan keuangan dan aplikasi pengetahuan keuangan tersebut dalam kehidupan seharihari. Maksud dari pengetahuan keuangan adalah pengetahuan individu mengenai penggunaan produk keuangan yang didapatkan melalui pendidikan atau pengalaman yang pernah didapatkan. Adapun aplikasi dari pengetahuan keuangan tersebut didefinisikan sebagai kemampuan seseorang serta kepercayaan diri seseorang dalam menggunakan pengetahuannya untuk terampil menggunakan produk keuangan.

Gambar 2.1. Hubungan antara Literasi, Pengetahuan, Edukasi, dan Kesejahteraan Keuangan

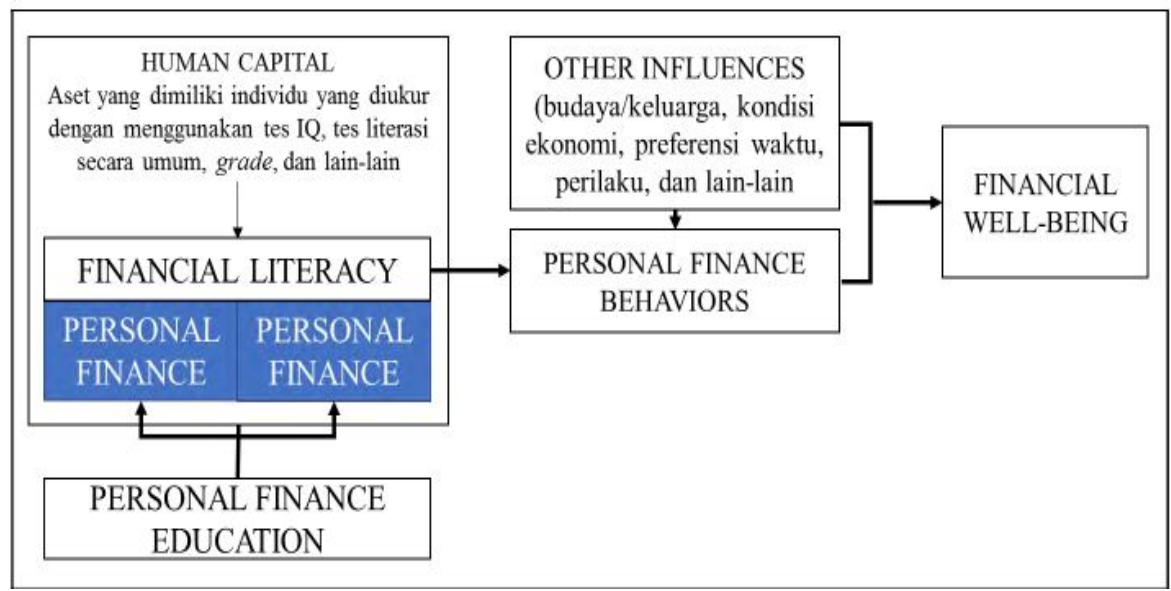

Otoritas Jasa Keuangan (OJK) Republik Indonesia merupakan sebuah lembaga Pelaksanaan Edukasi yang memiliki peran dalam meningkatkan keuangan masyarakat. OJK mengkategorikan tingkat literasi keuangan masyarakat Indonesia menjadi empat, yaitu:

1) Well literate, berarti individu tersebut memiliki pengetahuan tentang lembaga jasa keuangan serta produk jasa keuangan, memiliki keyakinan terhadap produk keuangan yang dipilih, serta memiliki keterampilan dalam menggunakan produk dan jasa keuangan

2) Sufficient literate, berarti individu tersebut memiliki pengetahuan dan keyakinan tentang lembaga jasa keuangan serta produk dan jasa keuangan, termasuk fitur, manfaat dan risiko, hak dan kewajiban terkait produk dan jasa keuangan. 
3) Less literate, berarti individu tersebut hanya memiliki pengetahuan dan pemahaman tentang lembaga jasa keuangan, produk dan jasa keuangan.

4) Non literate, berarti individu tersebut benar-benar tidak memiliki pengetahuan dan keyakinan terhadap lembaga jasa keuangan serta produk dan jasa keuangan, serta tidak memiliki keterampilan dalam menggunakan produk dan jasa keuangan.

Penulis menyimpulkan bahwa literasi keuangan merupakan cara membantu dalam memberikan pemahaman tentang mengelola keuangan dengan baik dan peluang untuk mencapai kinerja keuangan yang baik dimasa yang akan datang. Dengan kata lain literasi keuangan dapat digunakan sebagai salah satu alat bantu yang perlu ditingkatkan seseorang atau individu apabila mau memiliki kinerja keuangan yang baik dan berkembang.

\section{Metodologi Penelitian}

Penelitian ini bertujuan untuk menguji pengaruh literasi keuangan terhadap kinerja keuangan,perilaku pengelolaan keuangan pengurus koperasi sebagai intervening. Penelitian ini bersifat deskriptif analisis yaitu penelitian untuk menggambarkan dengan lebih teliti ciri-ciri usaha untuk menentukan frekuensi terjadinya sesuatu atau hubungan sesuatu yang lain dan memberikan gejala-gejala, fakta-fakta atau kejadian - kejadian secara sistematis dan akurat mengenai sifat sifat populasi atau daerah tertentu. Penelitian ini dilakukan di Bandar Lampung pada 7 Koperasi Pegawai Negeri Sipil, yaitu KPRI Saptawa, KPRI Betik Hati, KPRI Tiga Sehat, KPRI Betik Gawi, KPRI Kosuma SMPN 10, KPRI Intan Sejahtera IAIN Lampung dan KPRI Ragom Gawi.

Sumber data yang digunakan dalam penelitian adalah data primer.Data primer dilakukan melalui survei dimana instrumen yang digunakan adalah kuesioner.pertanyaan dijawab dengan menggunakan skala Likert.

\begin{tabular}{|c|c|c|c|c|}
\hline Variabel & Sub Variabel & Definisi & Indikator & Skala \\
\hline \multirow[t]{2}{*}{$\begin{array}{l}\text { Literasi } \\
\text { Keuangan } \\
\text { Adalah } \\
\text { pengetahuan } \\
\text { keuangan , } \\
\text { pemahaman } \\
\text { dan } \\
\text { kemampuan } \\
\text { untuk } \\
\text { mengaplikasi } \\
\text { kannya } \\
\text { (knowledge } \\
\text { and ability) }\end{array}$} & $\begin{array}{l}\text { Pengetahuan } \\
\text { (X1) }\end{array}$ & $\begin{array}{l}\text { Hanyamemiliki } \\
\text { pengetahuan } \\
\text { tentanglembaga } \\
\text { jasa keuangan } \\
\text { serta produk \& } \\
\text { jasa keuangan. }\end{array}$ & $\begin{array}{l}\text { 1. Pengetahuan } \\
\text { tentang } \\
\text { sistem } \\
\text { keuangan. } \\
\text { 2. Pengetahuan } \\
\text { tentang nilai } \\
\text { waktu uang. } \\
\text { 3. Pengetahuan } \\
\text { tentang } \\
\text { bunga. } \\
\text { 4. Pengetahuan } \\
\text { tentang kredit } \\
\text { dan debt. } \\
\text { Sumber } \\
\text { (Budiono, } \\
\text { 2011:11) }\end{array}$ & $\begin{array}{l}\text { Skala } \\
\text { likert }\end{array}$ \\
\hline & $\begin{array}{l}\text { Pemahaman } \\
\text { (X2) }\end{array}$ & $\begin{array}{l}\text { Memiliki } \\
\text { pengetahuan dan }\end{array}$ & $\begin{array}{l}\text { 1. Mengerti } \\
\text { tentang }\end{array}$ & $\begin{array}{l}\text { Skala } \\
\text { likert }\end{array}$ \\
\hline
\end{tabular}




\begin{tabular}{|c|c|c|c|c|}
\hline \multirow[t]{2}{*}{$\begin{array}{l}\text { Lusardi dan } \\
\text { Mitchell } \\
(2013)\end{array}$} & & $\begin{array}{l}\text { keyakinan tentang } \\
\text { lembaga jasa } \\
\text { keuangan serta } \\
\text { produk dan jasa } \\
\text { keuangan, } \\
\text { termasuk fitur, } \\
\text { manfaat dan } \\
\text { risiko, hak dan } \\
\text { kewajiban terkait } \\
\text { produk dan jasa } \\
\text { keuangan. } \\
\text { Otoritas Jasa } \\
\text { Keuangan, 2014 }\end{array}$ & $\begin{array}{l}\text { sistem } \\
\text { keuangan. } \\
\text { 2. Memiliki } \\
\text { pengetahuan } \\
\text { menganalisis } \\
\text { laporan } \\
\text { keuangan. } \\
\text { 3. Mengerti } \\
\text { cara } \\
\text { perhitungan } \\
\text { bunga. } \\
\text { 4. Mengerti } \\
\text { cara } \\
\text { mengelola } \\
\text { kredit dan } \\
\text { debt. } \\
\text { Sumber } \\
\text { (Budiono, } \\
\text { 2011:11) }\end{array}$ & \\
\hline & $\begin{array}{l}\text { Penerapan } \\
\text { (X3) }\end{array}$ & $\begin{array}{l}\text { Memiliki } \\
\text { pengetahuan dan } \\
\text { keyakinan tentang } \\
\text { lembaga jasa } \\
\text { keuangan serta } \\
\text { produk dan jasa } \\
\text { keuangan, } \\
\text { termasuk fitur, } \\
\text { manfaat dan } \\
\text { risiko, hak dan } \\
\text { kewajiban terkait } \\
\text { produk dan jasa } \\
\text { keuangan, serta } \\
\text { memiliki } \\
\text { keterampilan } \\
\text { dalam } \\
\text { menggunakan } \\
\text { produk dan jasa } \\
\text { keuangan. } \\
\text { Otoritas Jasa } \\
\text { Keuangan, 2014 }\end{array}$ & $\begin{array}{l}\text { 1. Mampu } \\
\text { melakukan } \\
\text { pencatatan } \\
\text { keuangan } \\
\text { sesuai } \\
\text { dengan } \\
\text { sistem } \\
\text { keuangan. } \\
\text { 2. Mampu } \\
\text { menganalisis } \\
\text { laporan } \\
\text { keuangan. } \\
\text { 3. Mampu } \\
\text { menghitung } \\
\text { dan } \\
\text { mengelola } \\
\text { bunga. } \\
\text { 4. Memliki } \\
\text { kemampuan } \\
\text { mengelola } \\
\text { kredit dan } \\
\text { debt. } \\
\text { Sumber } \\
\text { (Budiono, } \\
\text { 2011:11) }\end{array}$ & $\begin{array}{l}\text { Skala } \\
\text { likert }\end{array}$ \\
\hline Pengelolaan & angan (X4) & $\begin{array}{l}\text { Pengelolaan } \\
\text { keuangan adalah }\end{array}$ & $\begin{array}{l}\text { 1. Melakukan } \\
\text { Perencanaan }\end{array}$ & $\begin{array}{l}\text { Skala } \\
\text { likert }\end{array}$ \\
\hline
\end{tabular}




\begin{tabular}{|c|c|c|c|}
\hline & $\begin{array}{l}\text { proses } \\
\text { meramalkan, } \\
\text { mengumpulkan,m } \\
\text { engeluarkan, } \\
\text { menginvestasikan } \\
\text { dan } \\
\text { merencanakan kas } \\
\text { yang diperlukan } \\
\text { perusahaan atau } \\
\text { individu agar } \\
\text { dapat beroperasi } \\
\text { dengan lancar, }\end{array}$ & $\begin{array}{l}\text { Keuangan. } \\
\text { 2. Melakukan } \\
\text { Pencatatan } \\
\text { keuangan } \\
\text { sesuai } \\
\text { dengan } \\
\text { sistem } \\
\text { keuangan } \\
\text { koperasi dan } \\
\text { SAP } \\
\text { 3. Pengelolaan } \\
\text { Bunga } \\
\text { dengan Baik. } \\
\text { 4. Pengelolaan } \\
\text { Hutang dan } \\
\text { Piutang } \\
\text { dengan baik. } \\
\text { 5. Pengelolaan } \\
\text { Kas dengan } \\
\text { baik } \\
\text { Sumber } \\
\text { Zimmerere dan } \\
\text { Scarborough } \\
\text { (2008) }\end{array}$ & \\
\hline Kinerja Keuangan (Y) & $\begin{array}{l}\text { Kinerja Keuangan } \\
\text { adalah } \\
\text { kemampuan } \\
\text { perusahaan dalam } \\
\text { mengelola dan } \\
\text { mengendalikan } \\
\text { sumberdaya yang } \\
\text { dimilikinya. }\end{array}$ & $\begin{array}{l}\text { 1. Analisis } \\
\text { break even, } \\
\text { mengetahui } \\
\text { tingkat } \\
\text { pendapatan } \\
\text { yang harus } \\
\text { dicapai agar } \\
\text { tidak } \\
\text { mengalami } \\
\text { kerugian. } \\
\text { 2. Analisis } \\
\text { Sumber dan } \\
\text { Penggunaan } \\
\text { Modal Kerja. } \\
\text { 3. Analisis } \\
\text { Sumber dan } \\
\text { Penggunaan } \\
\text { Kas. } \\
\text { (Jumingan, } \\
\text { 2006:242) }\end{array}$ & $\begin{array}{l}\text { Skala } \\
\text { likert }\end{array}$ \\
\hline
\end{tabular}

3. Hasil dan Pembahasan 
Pengujian instrument dalam penelitian ini dilanjutkan dengan menggunakan metode partial least square (PLS).PLS merupakan metode alternative analisis dengan structural Equation Modeling (SEM) yang berbasis variance. Alat bantu yang digunakan berupa program smartPLS versi 3, yang dirancang khusus untuk mengestimasi persamaan structural dengan basis variance.

Gambar 3.1

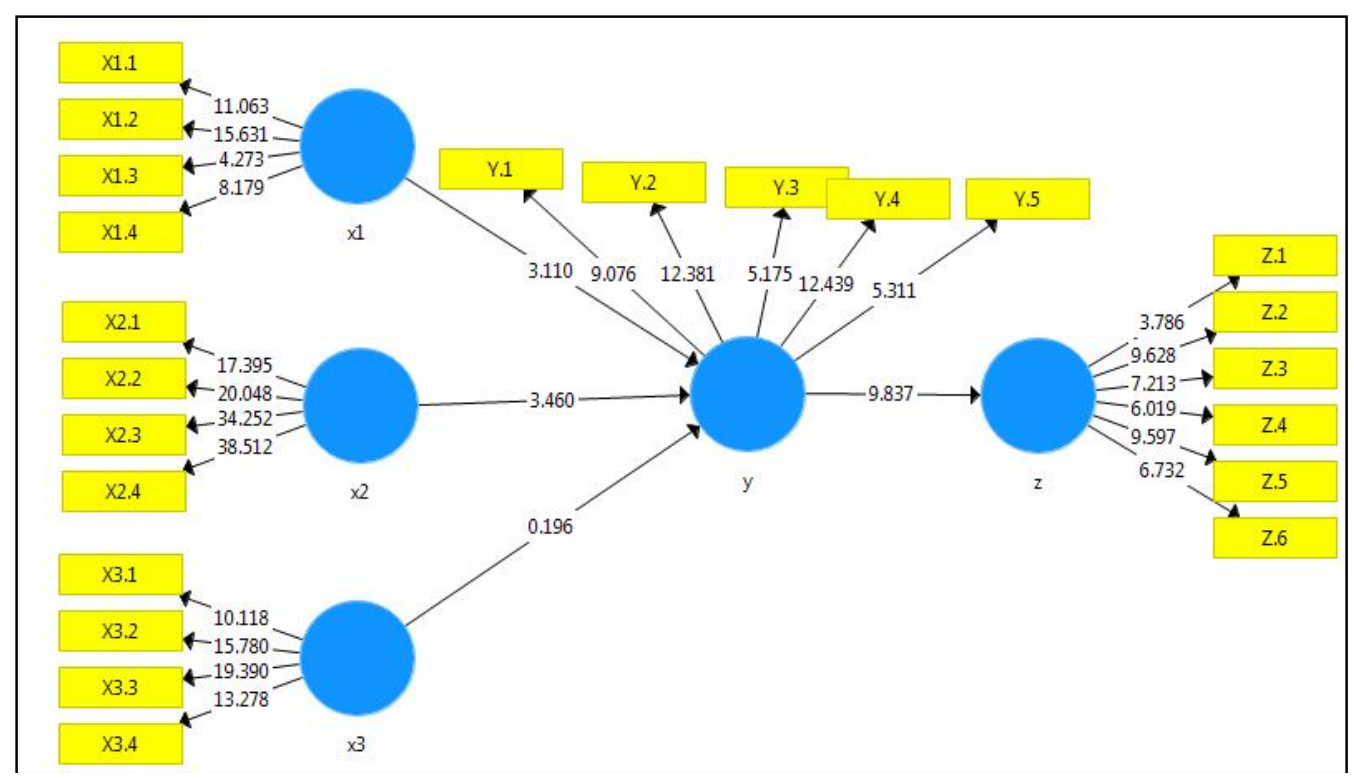

1. Pengaruh pengetahuan terhadap perilaku pengelolaan keuangan

HO : pengetahuan tidak berpengaruh terhadap perilaku pengelolaan keuangan

H1 : pengetahuan berpengaruh terhadap perilaku pengelolaan keuangan

Dari hasil perhitungan diatas diperoleh nilai t-statistik pengetahuan X1 sebesar 3.110 lebih besar dari nilai t table 1.6778 dan nilai $p$ value 0.002 lebih kecil dari 0.05 yang artinya Ho ditolak dan $\mathrm{H} 1$ diterima, berarti pengetahuan berpengaruh terhadap perilaku pengelolaan keuangan.

2. Pengaruh pemahaman terhadap perilaku pengelolaan keuangan

H0 : pemahaman tidak berpengaruh terhadap perilaku pengelolaan keuangan

$\mathrm{H} 2$ : pemahaman berpengaruh terhadap perilaku pengelolaan keuangan

Dari hasil perhitungan diatas diperoleh nilai t-statistik pemahaman X2 sebesar 3.460 lebih besar dari nilai t table 1.6778 dan nilai $p$ value 0.001 lebih kecil dari 0.005 yang artinya $\mathrm{H} 0$ ditolak dan $\mathrm{H} 2$ diterima berarti pemahaman berpengaruh terhadap perilaku pengelolaan keuangan.

\section{Pengaruh penerapan terhadap perilaku pengelolaan keuangan}

H0 : penerapan tidak berpengaruh terhadap perilaku pengelolaan keuangan

H3 : penerapan berpengaruh terhadap perilaku pengelolaan keuangan 
Dari hasil perhitungan diatas diperoleh nilai t-statistik penerapan X3 sebesar 0.196 lebih kecil dari nilai t table 1.6778 dan nilai $\mathrm{p}$ value 0.844 lebih besar dari 0.005 yang artinya $\mathrm{H} 0$ diterima dan $\mathrm{H} 3$ ditolak, berarti penerapan tidak berpengaruh terhadap perilaku pengelolaan keuangan.

\section{Pembuktian intervening variable, pengaruh literasi keuangan terhadap kinerja keuangan melalui kesesuaian perilaku pengelolaan keuangan.}

HO :literasi keuangan tidak berpengaruh terhadap kinerja keuangan melalui kesesuaian perilaku pengelolaan keuangan

H4 :literasi keuangan berpengaruh terhadap kinerja keuangan melalui kesesuaian perilaku pengelolaan keuangan

Berdasarkan hasil pengolahan data diatas dapat diketahui nilai pengaruh langsung antara variable perilaku pengelolaan keuangan terhadap kinerja keuangan adalah sebesar 0.681 sedangkan pengaruh tidak langsung antara variable $\mathrm{x} 1, \mathrm{x} 2$ dan $\mathrm{x} 3$ terhadap kinerja keuangan melalui perilaku pengelolaan keuangan sebesar 0.0051 (0.367 x $0.480 \times 0.029)$. dengan membandingkan kedua nilai tersebut dapat dibuktikan bahwa pengaruh variable pengetahuan $\mathrm{X} 1$, pemahaman $\mathrm{X} 2$, dan penerapan X3 terhadap kinerja keuangan secara langsung lebih kecil dari pada pengaruh variable pengetahuan $\mathrm{X}$ 1, pemahaman $\mathrm{X}$ 2dan penerapan $\mathrm{X} 3$ terhadap kinerja keuangan $\mathrm{Z}$ melalui perilaku pengelolaan keuangan $\mathrm{Y}$, sehingga dapat disimpulkan bahwa perilaku pengelolaan keuangan merupakan intervening bagi literasi keuangan dengan kinerja keuangan.

\section{Evaluasi goodness of fit}

Analisis ini digunakan untuk mengetahui apakah model yang dihasilkan cukup baik untuk menjelaskan fenomena yang dikaji. Dari hasil analisis goodness of fit model diperoleh nilai q square :

$\mathrm{Q}^{2}=1-\left(1-\mathrm{R}_{1}{ }^{2}\right)\left(1-\mathrm{R}_{2}{ }^{2}\right)$

$=1-(1-0.556)(1-0.464)$

$=1-0.237984$

$=0.762016$

Hal ini mengindikasikan bahwa dari perhitungan statistic, maka model sudah baik. Karena variasi variable yang terlibat dalam model telah mampu menjelaskan variable-variabel yang mempengaruhi kinerja keuangan sebesar $76.20 \%$ sisanya $23.80 \%$ merupakan factor lain yang turut mempengaruhi kinerja keuangan termasuk di dalamnya adalah standar eror.

Hasil penelitian ini bertujuan untuk memberikan jawaban dari rumusan masalahyang telah dikemukakan pada bab sebelumnya. Berdasarkan hasil pengujian hipotesis dengan menggunakan metode-metode diatas dapat dijelaskan sebagai berikut :

\section{Pengaruh pengetahuan terhadap perilaku pengelolaan keuangan.}

Hasil uji hipotesis adalah $\mathrm{H0}$ ditolak dengan arti pengetahuan berpengaruh terhadap perilaku pengelolaan keuangan, hasil ini sesuai dengan teori yang dikemukakan oleh Remund (2010), pengetahuan adalah salah satu aspek yang umum dan sekaligus harus dimiliki dalam konteks literasi keuangan. Agar dapat mengelola keuangan seseorang harus memiliki pengetahuan yang kuat tentang 
keuangan, semakin baik pengetahuan pengurus tentang literasi keuangan, semakin baik pula dalam mengelola keuangan koperasi. Didasarkan pada hasil penelitian yang peneliti lakukan, tingkat pendidikan pengurus koperasi pegawai negeri Bandar lampung rata-rata adalah strata 1 dengan latar belakang pendidikan yang berbeda-beda, tidak semua pengurus merupakan lulusan dari latar belakang keuangan, tapi pada dasarnya mereka diberikan pembekalan mengenai literasi keuangan berupa workshop, seminar dan pembelajaran tentang keuangan koperasi, sehingga dapat dikatakan pengetahuan yang mereka miliki tentang keuangan itu baik, ini sejalan dengan hasil pengujian hipotesis 1 yang artinya pengetahuan berpengaruh terhadap perilaku pengelolaan keuangan pada koperasi pegawai negeri bandar lampung.

\section{Pengaruh pemahaman terhadap perilaku pengelolaan keuangan}

Hasil uji hipotesis $\mathrm{H} 0$ ditolak dan $\mathrm{H} 2$ diterima, artinya pemahaman berpengaruh terhadap perilaku pengelolaan keuangan, hal ini searah dengan teori yang dikemukakan Budiono (2012), bahwasanya seseorang yang mempunyai basic personal finance, berarti seorang tersebut mempunyai pemahaman mengenai suatu sistem keuangan, seperti perhitungan bunga, biaya peluang, nilai waktu, likuiditas dan lain sebagainya, artinya semakin banyak pemahaman pengurus koperasi mengenai literasi keuangan semakin baik pula perilaku pengelolaan keuangan koperasi. Berdasarkan penelitian ini literasi keuangan yang diukur pada perilaku pengelolaan keuangan koperasi berkaitan dengan pemahaman mengenai nilai tukar, fitur jasa layanan keuangan, pencatatan keuangan, sikap dalam mengeluarkan keuangan yang mencakup pemahaman menyusun anggaran penghasilan yang akan diterima oleh masingmasing anggota dan pengurus koperasi. Semakin baik pemahaman pengurus koperasi mengenai literasi keuangan maka akan semakin baik pula perilaku pengelolaan keuangan yang berdampak pada hasil pengelolaan keuangan koperasi. Hal ini sejalan dengan hasil pengujian hipotesis kedua yaitu pemahaman berpengaruh terhadap perilaku pengelolaan keuangan koperasi pegawai negeri bandar lampung.

\section{Pengaruh penerapan terhadap perilaku pengelolaan keuangan}

Hasil uji hipotesis ketiga adalah $\mathrm{H} 0$ diterima dan $\mathrm{H} 3$ ditolak, artinya penerapan tidak berpengaruh terhadap perilaku pengelolaan keuangan. Ini sesuai dengan kategori yang dikemukakan oleh otoritas jasa keuangan OJK yaitu pengurus koperasi pegawai negeri bandar lampung masuk dalam kategori Less literate, berarti individu tersebut hanya memiliki pengetahuan dan pemahaman tentang lembaga jasa keuangan, produk dan jasa keuangan. Artinya para pengurus memiliki sumber daya manusia yang baik dengan dibekali pengetahuan dan pemahaman saja, secara prakteknya pengurus koperasi tidak mempunyai keterampilan literasi keuangan dalam pengelolaan keuangan, dan hanya sebatas dengan pengetahuan dan pemahaman yang diperoleh dari workshop, dan seminar, sehingga penerapan dalam literasi keuangan tidak berpengaruh terhadap perilaku pengelolaan keuangan. Hal ini disebabkan karena sebagian dari latar belakang pendidikan mereka bukan berasal dari keuangan, rekruitmen pergantian pengurus koperasi juga tidak didasarkan pada latar belakang 
pendidikan keuangan tetapi dilihat dari jabatan dan kedekatan personal antar pengurus. Dalam perilaku pengelolaan keuangan tidak hanya dibutuhkan pengetahuan dan pemahaman saja mengenai literasi keuangan tetapi juga perlu adanya penerapan atau keterampilan dalam pengelolaan keuangan. Hasil pengujian hipotesis mengartikan penerapan tidak berpengaruh terhadap perilaku pengelolaan keuangan.

\section{Pengaruh literasi keuangan terhadap kinerja keuangan melalui variabel intervening perilaku pengelolaan keuangan}

Hasil uji hipotesis ke empat menunjukkan bahwa $\mathrm{H} 0$ ditolak dan $\mathrm{H} 4$ diterima, artinya literasi keuangan berpengaruh terhadap kinerja keuangan melalui kesesuaian perilaku pengelolaan keuangan, Menurut Zimmerere dan Scarborough (2008) perilaku pengelolaan keuangan adalah proses meramalkan, mengumpulkan, mengeluarkan, menginvestasikan dan merencanakan kas yang diperlukan perusahaan atau individu agar dapat beroperasi dengan lancar.Keberhasilan dalam mengelola keuangan koperasi sangat dipengaruhi oleh perilaku personal didalam penguruskoperasi, pengetahuan atau pemahaman carapengelolaan, gaya hidup dan tujuan keuangan (tujuan jangka pendek, menengah dan panjang dari keluarga).Huston (2010) mengungkapkan bahwa dengan seseorang memiliki literasi keuangan yang baik ditambah dengan perilaku dalam mengelola keuangan yang tepat maka orang tersebut dapat dikatakan sejahtera dalam hal keuangannya, dengan demikian untuk bisa sejahtera literasi keuangan harus menimbulkan perilaku pengelolaan keuangan yang baik, Karena dengan seseorang pengurus memiliki skill yang baik dalam mengelola keuangannya, pengurus koperasi tersebut akan terhindar dari masalah keuangan sehingga kinerja keuangan koperasi akan tercapai dengan maksimal. Hal ini sesuai dengan hasil pengujian hipotesis yang berarti literasi keuangan berpengaruh terhadap kinerja keuangan melalui kesesuaian perilaku pengelolaan keuangan pada koperasi pegawai negeri bandar lampung.

\section{Kesimpulan dan Saran}

\section{Kesimpulan}

Dari hasil pembahasan pada bab sebelumnya didapatkan kesimpulan sebagai berikut :

1. Agar dapat mengelola keuangan seseorang harus memiliki pengetahuan yang kuat tentang keuangan, semakin baik pengetahuan pengurus tentang keuangan, semakin baik pula dalam mengelola keuangan koperasi.

2. seseorang yang mempunyai basic personal finance, berarti seorang tersebut mempunyai pemahaman mengenai suatu sistem keuangan, seperti perhitungan bunga, biaya peluang, nilai waktu, likuiditas dan lain sebagainya, artinya semakin banyak pemahaman pengurus koperasi mengenai literasi semakin baik pula perilaku pengelolaan keuangan koperasi.

3. pengurus koperasi pegawai negeri bandar lampung masuk dalam kategori Less literate, berarti individu tersebut hanya memiliki pengetahuan dan 
pemahaman tentang lembaga jasa keuangan, produk dan jasa keuangan. Artinya para pengurus memiliki sumber daya manusia yang baik dengan dibekali pengetahuan dan pemahaman saja, secara prakteknya pengurus koperasi tidak mempunyai keterampilan literasi keuangan dalam pengelolaan keuangan, dan hanya sebatas dengan pengetahuan dan pemahaman yang diperoleh dari workshop, dan seminar, sehingga penerapan dalam literasi keuangan tidak berpengaruh terhadap perilaku pengelolaan keuangan. Hal ini disebabkan karena sebagian dari latar belakang pendidikan mereka bukan berasal dari keuangan, rekruitmen pergantian pengurus koperasi juga tidak didasarkan pada latar belakang pendidikan keuangan tetapi dilihat dari jabatan dan kedekatan personal antar pengurus.

4. seseorang memiliki literasi keuangan yang baik ditambah dengan perilaku dalam mengelola keuangan yang tepat maka orang tersebut dapat dikatakan sejahtera dalam hal keuangannya, dengan demikian untuk bisa sejahtera literasi keuangan harus menimbulkan perilaku pengelolaan keuangan yang baik, Karena dengan seorang pengurus memiliki skill yang baik dalam mengelola keuangannya, pengurus koperasi tersebut akan terhindar dari masalah keuangan sehingga kinerja keuangan koperasi akan tercapai dengan maksimal.

\section{Saran}

Dari hasil penelitian diatas perlu adanya masukan sebagai sumbangsih untuk koperasi pegawai negeri bandar lampung dan untuk penelitian selanjutnya :

1. Perlu adanya seleksi atau rekruitmen yang sesuai dengan latar belakang pendidikan agar suatu tujuan organisasi yang dikelolanya menghasilkan hasil yang optimal.

2. Penelitian selanjutnya diharapkan menambah indikator tentang literasi keuangan agar hasil penelitian lebih luas.

3. Penelitian selanjutnya diharapkan tidak hanya membahas kinerja keuangan koperasi tetapi juga membahas tentang kesejahteraan para pengurus dan anggota, serta sampel yang diambil bisa diperluas dengan menambah koperasi diluar koperasi pegawai negeri bandar lampung.

\section{Daftar Pustaka}

Alhenawi Yasir dan Elkhal Khaled.Financial Literacy of U.S Household: Knowlage Vs. Longterm Financial Planning. Financial services review 22, pp. 211-244. 2013

Anastasia Sri Mendari dan Suramaya Suci Kewal."Tingkat literasi keuangan dikalangan mahasiswa STIE Musi’.Journal Economia, Vol: 9, No.2, pp.130-140. 2013 
Badan Pusat Statistik https://www.bps.go.id/statictable/2014/01 /30/1321/tabelperkembangan-koperasi-pada-periode-1967--2015.html. 2014

Effran Kurniawan. http://www.lampost.co/berita-2204-koperasi-di-lampung-terancamdibubarkan. 2018

Gujarati, Damodar, Ekonometri Dasar. Terjemahan: Sumarno Zain, Jakarta: Erlangga. 2003

Hilgert, \& j. Household financial management :The Connection between Knowledge and Behavior. Federal Reserve Bulletin, pp309-322. 2003

Huston Sandra J. Measuring financial literacy, Journal of consumer affairs, Vol: 4 No.2, pp. 296-315. 2010

Imam Ghozali. Aplikasi Analisis Multivariate dengan Program PLS. Badan penerbit Universitas Diponegoro. Semarang. 2006

Jensen dan meckling, the theory of the firm; manajerial behavior agency cost, journal of financial and economics, 3:305-360. 1976

Kadir.Analisis statistik deskriptif dan Analissis statistik terapan.Penerbit raja grafindo, Jakarta. 2016

Lusardi dan Mitchell, 'Planning and Financial Literacy', American Economic Review . Maksum, Azhar. Pidato Pengukuhan Guru Besar: Tinjuan atas Good Corporate Governance di Indonesia. 2005. Medan: Fakultas Ekonomi Universitas Sumatra Utara. 2013

Otoritas Jasa Keuangan. Literasi Keuangan. Retrieved Oktober 6, 2016, from https://www.ojk.go.id/id/kanal/edukasi-dan-perlindungan-konsumen/berita-dankegiatan/siaran-pers/Pages/siaran-pers-ojk-gelar-kegiatan-edukasi-keuangan-diyogyakarta.aspx, 2014

Sugiyono.Metode Penelitian Kuantitatif Kualitatif dan R\&D. Bandung: Alfabeta. 2014

Sujarweni, Wiratna. SPSS Untuk Penelitian.Yogyakarta : Pustaka Baru Press. 2015

Syofian, Siregar. Metode Penelitian Kuantitatif, Jakarta:Kencana. 2015 
Taft, Marzieh Kalantarie, Hosein Zare Zardeini, Mehrizi Seyyed Mohammad Tabatabaei dan Roshan Abdoreza. The Relation between Financial Literacy, Financial Wellbeing and Financial Concerns.International Journal of Business and Management Vol. 8, No. 11.2013.

Perry, Vanessa G. and Marlene D. Morris, Who is Control?The Role of Self.Perception, Knowledge, and Income in Explaining Consumer Financial Behaviour; Journal of Personal finance, vol. 8, 170-184. 2005

Wursanto.Dasar-Dasar Ilmu Organisasi. Yogyakarta:Penerbit Andi. 2003

Zimmerere, T.W. and Scarborough, N.M. Efeective small business management: and entrepreurial approach. 6th Ed. 2008 